\title{
Transformation of the Term "Real Estate" in Russia in the Context of Integration and Digitalization
}

\author{
Alexey Anisimov ${ }^{1, *}$ Irina Grebenkina ${ }^{1}$ \\ ${ }^{I}$ Department of Civil Law, Kutafin Moscow State Law University (MSAL), Moscow 125993, Russian Federation \\ "Corresponding author. Email: avanisimov@msal.ru
}

\begin{abstract}
The term "real estate" in Russian legislation and doctrine still causes major discussions, controversies in law enforcement practice as there is no unified understanding of what should be regarded as immovable and whether this distinction still should be provided in the legislation. This paper is dedicated to the criteria used to define real estate and the question of the unity of a land plot and buildings on them both in Russian and foreign legislation. The authors, based on the analysis of the positive experience of the developed continental foreign legal order and the prevailing significance of the "national" nature of law, determine the vectors of improvement of the current Russian civil legislation on real estate in the context of integration and digitalization.
\end{abstract}

Keywords: Real estate, land plot, immovable property criteria, modernization, single real estate object.

\section{INTRODUCTION}

The Clause 1 of Article 130 of the Civil Code of the Russian Federation (hereinafter - C.C.R.F.) establishes the "concept of immovable things", which is synonymous with the "concept of immovable property and real estate" [1]. The C.C.R.F. refers to real estate the following objects: "land plots, subsoil plots and everything that is firmly connected with land, that is, objects, the movement of which is impossible without disproportionate damage to their purpose, including buildings, structures, and objects of unfinished construction" [1]. In addition, real estate includes aircrafts and sea vessels subject to state registration, and inland navigation vessels. Other property may also be classified as immovable by law. "In 2015, space objects were excluded from the list of real estate. The novelty of 2016 was the assignment of residential and non-residential premises to immovable property, as well as parts of buildings or structures (parking spaces) intended for the placement of vehicles, if the boundaries of such premises, parts of buildings or structures are described in accordance with the procedure established by the legislation on state cadastral registration" [1]. We believe that the above formulation of the concept of real estate needs modernization, since it is characterized by vague and insufficient completeness, which gives rise to several theoretical and practical problems, which will be considered below. In order to correctly determine the vectors for improving the current Russian civil legislation on real estate, it is important, first of all, to determine and analyze the criteria for classifying certain objects as real estate and, in fact, the very content of this term, taking into account the positive experience of the developed continental foreign law and the prevailing "national" nature of the law. This study is based on the principles of complex and comprehensive consideration and assessment of criteria for real estate, its content through the analysis of Russian and foreign doctrine, legislation, and current judicial practice. The authors pay considerable attention to comparative legal methodology, methods of legal analysis, weighing of interests, legal axiology, taking into account the principle of the unity of theory and practice.

\subsection{Related Work}

Many lawyers, scientists and legal practitioners have discussed the term "real estate" for decades without forming a unified approach to it.

Several problematic issues have arisen in all works about real estate in Russia and abroad:

1. What is considered real estate, what constitutes its content?

2. How to separate movable things form immovable? What are the criteria for that?

3. How does natural and artificial real estate correspond to each other?

Such legal researchers as Sukhanov [2], Bevzenko [3], Markwarth [4], Von Bar [5], Diez-Picazo [6] dedicated some of their works to the problems of identifying the real estate.

\subsection{Our Contribution}

This article defines a set of criteria for identifying property as immovable, taking into account the advantages and disadvantages of various approaches based on an analysis of legislation, doctrine and actual judicial practice. The authors investigate foreign legislation (Germany, Estonia, Switzerland, France, China, Great Britain) on the concept of real estate and its content, with the subsequent classification of foreign legal orders into 4 groups. The advantages of the model of a single object of immovable property are evaluated, when only a land plot is recognized as 
real estate, and all buildings on it are its constituent parts, with some justified exceptions. Concrete proposals are formulated for the reception of this model into Russian civil legislation, taking into account the peculiarities of the national character of civil law and Russian civil circulation. Results of this research can be useful for foreign scientists and practitioners.

\subsection{Paper Structure}

The next part of the text is structured as follows. In section 2 the authors investigate various criteria for real estate, analyse legislation, jurisprudence and doctrine, formulate conclusions on the unification of identifying signs of real estate. Section 3 analyses the unity of the land plot and the buildings on it. Finally, section 4 examines foreign legal orders. Section 5 presents key findings from the work.

\section{CRITERIA FOR CLASSIFYING THINGS AS REAL ESTATE}

The C.C.R.F. formulates two criteria for classifying things as real estate - a strong connection with the land and an indication of the law. Based on these criteria, land and subsoil plots are a priori classified as real estate. All other property becomes immovable through "a connection with the land and the impossibility of moving it without disproportionate damage to its purpose or through an indication in federal law" [1]. At the same time, technically, the legislator uses the method of listing real estate objects, which, for one reason or another, are considered real property even without special connection with the land plot (for example, aircraft and ships). "The definition of the C.C.R.F. has been repeatedly criticized, both in connection with the content" [7] and "in connection with the technical wording" [8].

The problem of applying the concept of real estate is further complicated by the fact that a number of clarifying features of real estate may be contained in other laws, including giving new interpretations to this concept, which gives rise to a number of practical problems, for example, determination of the composition of a unified real estate complex, recognition of apartments in an unfinished construction object as an independent object of immovable property, recognition of a part of a premise and a part of a land plot as an independent object of immovable property, disputes over the recognition of fences, pavements of a land plot, road surfaces, football and other sports stadiums, construction machinery (for example, tower cranes), equipment, etc. as real estate. The resolution of these issues is of extreme practical importance for taxation, as well as state registration of certain transactions with real estate, for example, lease agreements. Professor Alexeev rightly notes "scientists have expressed mutually exclusive points of view, which negatively affects the effectiveness of legal regulation of relations related to real estate and the stability of judicial practice" [8].

"The doctrine highlights a number of criteria that refute the status of real estate, regardless of the presence of a strong connection with the land plot: lack of state registration of rights" [9], "lack of state cadastral registration" [10], "violation of the law when creating a thing (unauthorized construction)" [11], "lack of independent economic purposes" [12], "limited expected time period for using the object" [13].

The absence in the legislation of clear criteria for classifying certain objects of civil turnover as real estate turns this category into evaluative category. The existence of an evaluative concept in itself is not problematic, but it is desirable that the legislator strives to set the framework and criteria for evaluation. An attempt to set such a framework was made in the Resolution of the Plenum of the Supreme Court of the Russian Federation of 23.06.2015 № 25 (hereinafter - the Resolution 25). Clause 38 of the resolution states that "the thing is immovable either by virtue of its natural properties (paragraph one of paragraph 1 of Article 130 of the C.C.R.F.), or by virtue of the direct indication of the law that such an object is subject to the regime of immovable things (paragraph two of paragraph 1 of Article 130 of the C.C.R.F.)" [1]. Obviously, the criteria of a connection with the land is a sign of the physical property of a thing, which means that any legal signs (such as legal relations regarding this property) of this thing are excluded from the assessment framework. Considering the digitalization of the economy and society, the conclusion drawn in the said Resolution regarding the state registration of a real estate object is also debatable. Information and communication technologies "support competitiveness and are the driving force of economic development" [14]. "The integration of digital technologies in everyday life (digitalisation) leads to the rethinking of business processes, the transformation of business models, change in marketing management systems and in consumer behaviour" [15]. According to the Resolution 25 state registration doesn't as a general rule influence the recognition of property as immovable. Therefore, everything built before the system of registration was introduced should be regarded as immovable property although the rights were not registered. The concept of registration, which was actively proposed by researchers [9] was refuted in judicial practice. For comparison, in Germany, the closest "legal relative" of Russia, the situation is exactly the opposite. Thus, "in accordance with the Regulation on the Land Register, it follows that a land plot is a territorially limited part of the land surface, which is recorded on a separate sheet in the 
land register or under an individual number in the inventory list on a personified sheet of the land register. It is fundamentally important to note here that the fact of its reflection in the land register is of fundamental importance for the recognition of an object as a land plot. By itself, this fact of registration is the basis for the registered object to be regarded and considered as a land plot" [4].

The criteria for the independence of a real estate object and temporality are also of interest. So, the criterion of independence assumes that a real estate object that is part of an immovable property complex is not itself an object of immovable property (this most often refers to paving, fences, etc., objects associated with a land plot, but at the same time nonindependent real estate). Independence should also be considered in terms of the physical characteristics of the property, regardless of legal relationship. $n$ the light of the criterion of independence, the issue of attributing reclamation systems to independent real estate objects deserves attention. According to the Law on reclamation (1996), "reclamation systems are complexes of interconnected hydraulic and other structures and devices on reclaimed lands (for example, canals, collectors, pipelines, reservoirs, dams, pumping stations, water intakes) that ensure the creation of optimal soil regimes. Obviously, land reclamation facilities are an improvement of the land plot and are an integral part of it, in this regard, it is impossible to consider them as an independent object of immovable property. Most of the time, the qualification of land reclamation structures as part of a land plot is associated with putting them on the balance sheet" [16]. If they are on the balance sheet, they can be considered part of an immovable property complex. The situation is similar with road surfaces, paved grounds, sports stadiums and other similar facilities.

Similar controversial issues arise in foreign judicial practice. "For example, had to do with a dispute about the realisation in money of irrigation systems that had been sold but were on a Grundstück burdened with a hypothec. The court accepted that, by force of the agreement, the hypothec extended to the irrigation systems. On the one hand, they were movable goods under Article 111 of the Mortgage Act (Ley Hipotecaria, LH), but at the same time also (as accessories) inmuebles por destinación or pertenencias. Given this background of a dual characterisation of such things, scholarly writing has been forced to distinguish between 'genuine' and 'improper' immovables and has noted that the Spanish CC, in contrast to the French civil code, does not state that all things are either movables or immovables; it only states that they are to be regarded as either movables or immovables" [6, 210 p.].

The temporality / permanence of a real estate object is a rather controversial criterion. "This approach recognizes the decisive legal goal of building an object on a land plot (for temporary or permanent needs) ... if the object was erected ... obviously for a specific period ... then it is not possible to recognize it as real estate" [17]. The same approach is followed by Novikov, who believes that "an immovable object that is erected on a leased land plot, the lease agreement of which requires the lessee to return the land plot free of any buildings at the end of the lease cannot be subordinated to norms designed specifically for real estate, since these items should disappear soon" [7]. Of course, such a point of view seems to be polemical, because in general, everything on Earth is temporary, therefore, even the establishment of the term of use can give the object a temporary character, for example, leasehold rights in England for apartments for a period of 99 years. The contrast between the temporary nature and the concept of a capital construction object is also very controversial. "So, an object, the construction of which is not completed (hereinafter - objects of unfinished construction), with the exception of temporary buildings like kiosks, sheds and other similar buildings, is recognized as an object of capital construction according to the Town Planning Code of the Russian Federation" [18]. An indication of the temporary nature in this situation is a reference to the objects constructive, and not to its temporal characteristics. In the BGB $\S 95$ speaks "of "alleged" constituent parts of a land plot, underlining that temporary purposes of certain things do not belong to the constituent parts of a land plot" [19]. At the same time, an analysis of practice shows that the legislator in this definition of "temporality" again refers not to a time period, but to qualitative characteristics, so, for example, construction sheds fall under the application of this paragraph. There are no such norms in the civil law of Russia, judicial practice does not refer to them and does not consider the time criterion as determining for classifying an object as real estate. Furthermore, buildings and structures on leased land, despite the temporary nature of their existence, are registered as real estate [20].

Let us now consider the issue of classifying unfinished construction objects and unauthorized buildings as real estate. To the question of classifying unfinished construction objects as real estate, the Resolution answers affirmatively if there is a strong connection with the land, that is, the criterion of the physical properties of a thing is again used. With an unauthorized construction, the situation is somewhat different in light of the fact that such an object should not be considered an object of civil law at all, or rather, such an object requires an additional decision about the possibility of its existence and the potential emergence of the status of an object of civil law for it, or about the elimination of such an object. Therefore, the determination of the status of an unauthorized building as real estate directly depends on the decision on the admissibility of its existence and its transformation from an unauthorized construction 
into a real estate object. It can be concluded that an unauthorized building can be recognized as immovable property if it has a strong connection with the land, and at the same time a decision is made on the possibility of its recognition as an object of civil law.

The classification of property as immovable by virtue of the law is a legal criterion. Moreover, the presence of this criterion is actively discussed in the literature by Alexeev [8], Sukhanov [9], etc. On the one hand, it is obvious that the legislator, according to this criterion, classifies objects as real estate due to their importance and high cost (parking spaces, residential and non-residential premises, air and sea vessels, etc.), however, legal act stipulates the motivation to classify these objects as real estate. It should be noted that even in this category, changes are taking place, for example, space objects are excluded. In light of the launch of private space objects, their removal from the list of real estate objects seems questionable.

Recognition of real estate by virtue of law does not in any way correlate with the sign of a close connection with land, which becomes obvious when considering the list of objects classified as real estate by virtue of the law, although attempts to extend this criterion have been made several times. For example, Mayorova argues that "the strength of the bond of immovable things de jure with the land is determined indirectly, through the legal connection with the territory of the state of registration (flag), which is a condition for the operation of ships and space objects, a condition for their intended use" [21]. However, this conclusion is not without a fault for example in the case of ships.

The Resolution 25 clearly indicates that objects that do not have a close relationship with land are classified as real estate by virtue of the law, so there is no need to look for this sign from them. However, we see no need in treating aircrafts and ship differently from space ships. The virtue of law should not be extended to the objects that have no stable connection to land. In light of this, it is necessary to think about excluding such objects as ships, aircraft from the list of real estate in general. It seems logical to classify them as movable property that requires state registration, especially since the law provides for the possibility of state registration of certain movable property. For this reason, there is no legal or economical need in real estate by the virtue of law.

\section{THE UNITY OF THE LAND AND THE BUILDING ON IT?}

An important issue in the regulation of relations on the turnover of real estate is the correlation of the status of a land plot with the status of buildings on it. Russian legislation enshrines the principle of unity of rights to a land plot and a building (structure), while in the law and in legal practice these objects are considered as independent real estate objects. In Russian practice, a "dual" regime of real estate objects has developed, which is considered a "post-Soviet palliative" and a transition to the model of a single real estate object to avoid practical problems is proposed [3]. It is very important to subdivide real estate objects into natural (land and subsoil plots) and artificial (buildings, structures, etc.). "The civil legislation of the Russian Federation refers to real estate the land plot as well as what is built on it, at the same time separating these objects. From a practical point of view, such a division seems to be justified only in the case when the rights to the site and the building belong to different persons. In the case when the owner of the site and the building is one person, such a formal division seems to be unnecessary and creates problems in judicial practice" [3]. This is confirmed by the number of court cases in which the basis for recognizing the transaction as invalid is "a violation of the provisions of Article 35 of the Land Code of the Russian Federation, prohibiting the alienation of a land plot without buildings, structures located on it, if they belong to one person, and non-observance of the principle of the unity of the fate of the land plot and the building" [22].

At the moment, Draft of a Federal Law N 475386 is "On amendments to parts one, two, three and four of the C.C.R.F., as well as to certain legislative acts of the Russian Federation" is under consideration in the State Duma of the Russian Federation (hereinafter - Draft N 47538-6), which proposes the legislative consolidation in Russia of the construction of a single real estate object, similar to the European legal order (Germany, Switzerland, etc.). Only a land plot will be recognized as real estate, and all buildings on it - its constituent parts, if the same person acts as their owner. Buildings located on a plot of land should be regarded as integral improvements.

We believe that these amendments to the current Russian civil legislation are timely and reasonable, but, in our opinion, they need to be improved. We are confident that the concept of a single real estate object should not apply to apartment buildings and land plots below them. Also in a situation where the owners of a land plot and the building on it are different persons, the building should be considered not as an integral part of someone else's land plot, but as an integral part of a limited real estate development right (there is nothing about it in the Draft N 47538$6)$. At the same time, the right to build, like in foreign legal order, should be attributed to real estate, because of the following:

1. In practice difficulties arise in the situation of division of ownership of a plot and ownership of a building for different entities. A number of requirements must be met, such as, for example, the owner of the building has the right to erect this building on 
the site, the right to use someone else's site. From an economic point of view, such legal relations also give rise to certain obligations to compensate for the opportunity to use someone else's land plot, make appropriate payments, etc. The principle of unity of rights implies that the rights to the land plot and the building must follow together, so the owner of the building must be the owner of the title to the land plot, otherwise the implementation of the title to the building is not possible.

In this case, the question naturally arises: if the realization of the ownership right is associated with the right, why should the building be considered as a separate real estate object, and not as an integral part of the right that the developer has to the land plot. This concept is well known to other legal orders, for example, German law.

The independence of the building can be preserved in the event that it is impossible to secure the ownership of the land, as, for example, in England, where the land belongs to the Crown. At the same time, in England, the system of titles to land is widely developed, which allows the land to be involved in circulation, as if the land was the property of private individuals. However, this concept is difficult to transfer to Russian law.

In our opinion, in Russia, in a situation where the owner of a land plot and the owner of a building are different subjects, the rights to the building should be part of the rights to use the land plot and be included in the concept of real estate, and not regarded as some kind of "temporary property".

2 . The concept of a single real estate object however should not apply to apartment buildings and land plots below them. The existing system of the emergence of "ownership of an apartment in an apartment building and an automatic share in the ownership of the common property of an apartment building, which includes the land plot under the house, ensures the interests of Russian citizens as effectively as possible" [23].

This is an indisputable advantage of Russian legislation.

In Germany, according to the Law of March 15, 1951 (as amended on July 7, 2009) "On the ownership of residential premises and the right of durable use of residential areas" [24] owners of separate residential and non-residential premises are recognized as participants in shared ownership of buildings (an apartment building or a building used for non-residential purposes). However, to participate in civil relations, the right of each owner of the premises is considered as "special housing property" (Sondereigentum an einer Wohnung). According to $\S 30$ of this Law, "if the right of inheritance development belongs to several persons as a common shared right, any of the shares may be limited in such a way that each of the co-owners is given special ownership (Sondereigentum) for a certain residential or nonresidential premises in a building that has been or should be erected on the basis of the right of hereditary development (the right of hereditary development of residential premises, the right of hereditary development of non-residential premises)"'[24].

Thus, under German law, "a share in common property rights is granted, which is defined through the use of a legal fiction as a special property. However, the German model of the right to build an apartment building is not entirely acceptable in Russian realities, since in our law apartments and non-residential premises are recognized as independent objects of rights. Under German law, basically only "temporary ownership" exists for the period of validity of the right to build an apartment building or a building with non-residential premises" [25]. In Russia, purchasing an apartment in a building results not only in the acquiring of perpetual ownership right to the premises but also a shared right in common property.

\section{FOREIGN LEGAL PRACTICE: COMPARATIVE LEGAL ANALYSIS? THE ISSUE OF RECEPTION}

\section{- Germany}

In Germany, the concept of "real estate" is absent from the legislation. Instead of this term according to $\S 94-96$ of the German Civil Code (hereinafter BGB) the term "land plot" (Grundstück) is used. "Only the part of the earth's surface, that has established boundaries and is capable of being an object of property rights, is considered as Grundstück" [5]. "In accordance with $\S 94$ BGB clause 1, the essential constituent parts of a land plot include things that are firmly connected to the land and soil, in particular buildings, as well as products of the land plot as long as they are connected to the soil. The seed becomes an essential part of the land from the moment of sowing, the plant - from the moment of planting. $\$ 96$ BGB considers the rights related to the ownership of land (easement, building rights, encumbrances etc.)" [19] as its constituent parts. Real estate also includes temporary residential property in the interpretation of the Law "On Housing Property", which is primarily related to common shared ownership, as we wrote about earlier.

\section{- Estonia}

Section 127 (1) of the Estonian Property Rights Act "determines the spatial extent of immovable property, in particular, immovable property extends to the surface of the earth, as well as the airspace above it and the subsoil below it, to such a height or depth to which the interests of the owner extend when using the real estate. Clause 1 of Art. 148 of this Act stipulates that a structure extending across the border 
of an immovable is part of the immovable beyond which it goes if a real right is entered in the land register allowing construction. Section 241 (4) of the Estonian Property Rights Act provides that the provisions on immovables apply to the right of building, unless otherwise provided by law" [26]. Consequently, the Estonian legislator also identifies the terms "real estate» and "land plot", while buildings and structures are considered as constituent parts of a land plot and the right to build is also included in real estate.

\section{- Switzerland}

Section 19 of the Swiss Civil Code (hereinafter SCC) [27] deals with land ownership. Article 655 approx. 1 of Chapter 1 establishes that the "object of land ownership is all immovable property". "Real estate includes land plots and buildings on them; separate and permanent rights registered in the Land Register (eg. easements); mines (mines); shares in ownership of real estate. It should be noted that Swiss lawyers do not attribute the rights to real estate (mainly easements) to real estate itself; buildings are an integral part of the land plot" [27].

\section{- France}

Articles 517 - 526 of the French Civil Code of 1804 (hereinafter - FCC) determine "the list of objects related to real estate: property by nature (land and buildings, wind and water mills, anchored on piles and forming part of the building); according to their intended purpose (animals and objects placed by the owner on the land plot for his maintenance and management on it,); by virtue of the subject (usufruct established in relation to immovable things; easements, or encumbrances of land plots; right to claims for reclaiming immovable property)" [28]. Consequently, the French legislator does not adhere to the theory of a single object of real estate, similar to the legal order discussed above.

\section{- China}

In China, according to the 2007 Law On Property Rights of the People's Republic of China [29], the concepts of land and real estate are also distinguished. So, along with a land plot, real estate includes residential and non-residential premises, buildings, structures that have the status of independent objects of economic turnover. Under Article 42 of the said law, in the public interest, alienation of collectively owned land, residential and other real estate of organizations and individuals is allowed in accordance with the competence and procedure established by law. Article 58 "refers to movable and immovable property in collective ownership the following objects:

1) Lands, forests, mountains, pastures, virgin lands, sandbanks, which, in accordance with the law, are collectively owned;

2) Buildings and structures, means of production, systems of irrigation and cultivation of agricultural land, which are collectively owned;
3) Educational, scientific, cultural, health care, sports facilities that are collectively owned;

4) Other movable and immovable property that is collectively owned" [29].

Thus, in China, the list of real estate objects is not exhaustive, all objects are independent.

\section{- UK}

The concept of "immovables" is "identified with the term "real estate". In accordance with the provisions of English law, real estate should include land, as well as objects that have a connection with it - buildings, standing crops, livestock on a farm, etc. These objects are protected by filing a real claim against the defendant" [30] and are regarded as independent from each other.

Analysis of foreign legislation allows us to talk about four approaches regarding the content and correlation of the concepts of real estate, land plot and buildings on it:

1. As real estate only a land plot is considered, and everything associated with it (buildings, plantings, rights encumbering a land plot, shares in ownership of real estate - rights of obligation) is a part of it (Germany, Estonia, Switzerland, Italy, Japan);

2. It is impossible to establish the right to private ownership of land, which means that it is the building and structure that will be recognized as real estate (UK);

3 . Real estate is a generic collective concept that includes independent objects: land, buildings, structures, plantings, animals, agricultural implements, rights-encumbrances (France, Czech Republic);

4. Immovable things include independent objects: land plots, buildings, structures, parking spaces, residential, non-residential premises. Rights that encumber a land plot (easements, rent, etc.) do not belong to real estate (Russia, China).

\section{CONCLUSION}

From the said above, a number of conclusions can be drawn:

- The Russian legal system uses two criteria for classifying things as real estate - actual (strong connection with the land) and legal (recognition by virtue of law).

- The legal criterion for classifying real estate appears to be outdated, reflecting neither legal nor economic needs. Therefore, for objects that belong to real estate by virtue of the law and do not have a strong physical connection with the land plot, it is necessary to provide for a different regulatory regime and recognize some of them as movable things subject to state registration.

- At the same time, it is important to establish at the legislative level the criterion of independence of the real estate object. 
- We believe that the legislative consolidation in Russia of the construction of a single real estate object will provide permission for a number of previously indicated acute problems of law practice and the integration of Russian legislation on real rights with developed European legal order. At the same time, the concept of a single real estate object should not apply to apartment buildings and land plots below them. In case when the owners of the land plot and the building on it are different persons, the building should be considered not as an integral part of someone else's land plot, but as an integral part of a limited real estate development right. At the same time, the right to develop should be attributed to real estate.

\section{ACKNOWLEDGMENTS}

The work was carried out within the framework of the state assignment of the Ministry of Science and Higher Education of the Russian Federation No. 075-00293-20-02 dated May 25, 2020 for the implementation of the project on the topic No. FSMW2020-0030 "Transformation of Russian law in the face of great challenges: theoretical and applied foundations".

\section{REFERENCES}

[1] The C.C.R.F. (2020) http://www.consultant.ru/document/cons_doc_LAW_5142/ Accessed on 11 Aug 2020

[2] E.A. Sukhanov, Veschnoe pravo: nauchno-poznavatelnyi ocherk, Statut, 2017, 560 p.

[3] R.S. Bevzenko, Land Plot with the Structures on it, The Russian School of Private Law 17(1) (2017) 9-36. DOI: https://doi.org/10.24031/1992-20432017-17-1-9-36

[4] E. Markwarth (2017) The concepts of land ownership and real estate are identical in Germany. https://www.eg-online.ru/article/353718/ Accessed 01 Aug 2020

[5] C. Von Bar, Why do we need Grundstucke (land units), and what are they? On the difficulties of divining a European concept of "thing" in property law, Juridica International 22 (2014) 3. DOI: https://doi.org/10.12697/ji.2014.22.01

[6] L. Diez-Picazo (2008) https://ru.scribd.com/document/394205540/Diez-Picazo-Fundamentos-DelDerecho-Civil-Patrimonial-Funciones Accessed on 12 Aug 2020

[7] K.A. Novikov (2014) https://base.garant.ru/57574033/ Accessed 01 Aug 2020
[8] V.A. Alexeev (2017) http://alekseev-adv.ru/upload/iblock/e38/e3812a9a6ee4b704fc438366e63d0 704.pdf. Accessed 01 Aug 2020

[9] E.A. Sukhanov, O Ponyatii nedvijimosti I ego vliyanii na inie grazhdanko-pravovie kategorii, Vestnik grazhdankogo prava 4 (2008) 10-18.

[10] M.A. Dmitriev (2011) https://www.dissercat.com/content/kompleksy-nedvizhimogo-imushchestva-kak-obekty-grazhdanskikh-prav Accessed 01 Aug 2020

[11] V.V. Chubarov, Problemi pravovogo regulirovaniya nedvijimosti, Statut, 2006, 336 p.

[12] L. Lapach (2014) https://www.elibrary.ru/item.asp?id=23999471 Accessed on 14 Aug 2020

[13] K.A. Novikov, V.N. Sinelnikova (2015) https://id.hse.ru/data/2015/05/14/1098552793/Нови ков-Синельн.-текст_сайт.pdf Accessed on 14 Aug 2020

[14] I. Grebenkina, M. Vinogradova, V. Konstantinov, V. Prasolov, A. Lukyanova, Level Entrepreneurship-Role in the Digital Economy, Tendencies of Improvement of the Information Support System. Journal of Entrepreneurship Education 22(5) (2019) 2.

[15] S Grebenkina, O. Andreev, A. Lipatov, A. Aleksandrova, D. Stepanova, Modern information technology development trends in the global economy and the economies of developing countries, Espacios 40(42) (2019) 8-16.

[16] Codex (2019) http://docs.cntd.ru/document/9015302 Accessed 01 Aug 2020

[17] RSL (2003) https://search.rsl.ru/ru/record/01002723291 Accessed on 17 Aug 2020

[18] PCA consultant (2020) http://www.consultant.ru/document/cons_doc_LAW_51040/ Accessed 01 Aug 2020

[19] BGB (2020) https://www.gesetze-im-internet.de/englisch_bgb/ Accessed 01 Aug 2020

[20] Supreme Court of Russian Federation Decision of 14.02.2020 N 302-ЭC19-23916 Case N A3323998/2018 (2020) https://online3.consultant.ru Accessed on 08 Aug 2020

[21] ELD (2020) https://www.dissercat.com/content/nedvizhimaya-veshch-de-jure-kak-obekt-grazhdanskogo-prava-v-rossii-osobennosti-pravovogorez Accessed 01 Aug 2020

[22] Arbiter Court of North-West district Decision of 04.07.2017 N Ф07-6370/2017 Case N A66700/2015 (2015) https://online3.consultant.ru Accessed on 09 Aug 2020 
[23] Federal Law "On the Enactment of the Housing Code of the Russian Federation" dated December 29, $2004 \quad \mathrm{~N} \quad 189-\mathrm{FZ}$ https://online3.consultant.ru/cgi/online.cgi?req=doc\&base $=\mathrm{LAW} \& \mathrm{n}=353$ $358 \&$ dst=0\&rnd=29B9669DEC36E104414FB0EA CC5B2361\#042338525502599456 Accessed on 11 Aug 2020

[24] Gesetz über das Wohnungseigentum und das Dauerwohnrecht. https://www.gesetze-im-internet.de/woeigg/index.html Accessed on 01 Aug 2020

[25] I.A. Emelkina, Interesi biznesa v usloviyah reformi grajdanskogo zakonodatelstva o veschnykh pravakh, Zhurnal rossiskogo prava 1 (2015) 46-54.

[26] Estonian Property Rights Act (2020) https://www.riigiteataja.ee/akt/108072014007 Accessed on 22 Aug 2020

[27] SCC (2020) https://www.admin.ch/opc/en/classified-compilation/19070042/index.html Accessed on 01 Aug 2020

[28] FCC (2020) https://www.legifrance.gouv.fr/ Accessed on 01 Aug 2020

[29] JA (2019) https://www.juristaitab.ee Accessed on 01 Aug 2020

[30] M. Calikova, A. Pagaeva (2020) Ponyatie nedvijimosti $\mathrm{v}$ rossijskom I zarubejnom zakonodatelstve; sravnitelnij analiz. onhttp://jurnal.org/articles/2016/uri6.html Accessed on 01 Aug 2020 